\title{
The Effectiveness Of Teacher's Classroom Management Atstate Junior High School (Mtsn) 2 Medan, Indonesia
}

\author{
WahyudinNurNasution
}

\begin{abstract}
(State University for Islamic Studies of UIN Sumatera Utara, Indonesia) HP. 08128141690. Email:
ABSTRACT: The purpose of the research is to study the relationships of achievement motivation and selfconcept on the effectiveness of teacher's classroom management at StateJunior High School (MTsN) 2 Medan in Indonesia with 36 respondents selected randomly. The research used a survey method with correlation techniques. The research data was collected using questionnaires. All data were analyzed using statistical techniques of regression and simple correlation and plural. The results of the research indicate that there are positive correlations between (1) achievement motivation and the effectiveness of teacher's classroom management; (2) self-concept and the effectiveness of teacher's classroom management. Furthermore, there is a positive correlation between achievement motivation and self-concept with the effectiveness of teacher's classroom management.
\end{abstract}

\subsection{Background}

\section{INTRODUCTION}

The class is where the students learn, where most of the formal learning time of students takes place in the classroom. So, the activities can take place effectively and efficiently, the class must be managed either by the teacher. According to Achsin (1990), the first task of the teacher is to create a classroom atmosphere that supports the implementation of the learning process effective and efficient. Without the skill and ability of teachers to manage the classroom, then learning activities can not take place and achieve a predetermined goal. The emphasis on this capability is not intended to obviate the necessity of each teacher to master the other skills required to become a professional teacher.According to Suprihatiningrum (2016), classroom management skills related to the pedagogical competence. Classroom climate conducive to learning influence the success of teachers in delivering students achieve learning objectives. Learning process effective and efficient may occur if the circumstances support class (Winataputra, 2001). In addition, teachers can organize students, teaching facilities, and control means it in a nice atmosphere for the continuity of learning activities. Learning fun will allow optimum learning activities, and teachers can build a good relationship with learners.

In order to be more effective classroom management, teachers need to have achievement motivation. Achievement motivation is needed, so the teacher can help learners to achieve the learning objectives. Achievement motivation teachers can encourage students to interact with students and teachers to support the success of the learning process. With the existence of such interactions, the teacher can set goals, diagnose problems that occur in the classroom, providing assistance to students and strengthen the spirit of student learning.In an organization of the classroom, the teacher is a leader for students (Indrafachrudi and Lamberi, 1983). In order to lead effectively and efficiently in the classroom, teachers should have a high self-concept. By having a high self-concept (positive self-concept), one can use the perception effectively to achieve the learning objectives, build productive relationships with students and achieve success. In addition, teachers can have a profound understanding of themselves and the students.

The above description clearly illustrates ideal conditions we expect. However, based on observations of the early researchers in state junior high school (MTsN) 2 Medan, Indonesia found that there are still teachers who serve not only as a teacher as a class manager or manager classes. Classroom management activities observed by the researchers varied, there is a well planned, moderate, and less. Differences in the quality of classroom management have an impact on the quality of the learning process is applied.In other words, from the initial observation concluded that until now there are teachers who do not carry out their duties to the fullest in accordance with the expectations of government and society. This happens due to various factors, internal and external teachers. Inhibiting factors are thought to include such a lack of artistic ability to manage a class from the planning through to the evaluation phase, the lack of quality achievement motivation, poor morale and discipline, lack of cooperation between teachers, absence of coaching students, lack of attention to the welfare of teachers, lack of motivation of leadership, yet it has a high self-concept and others. 
Although there have been efforts from leaders state junior high school (MTsN) 2 Medan, Indonesia to improve the effectiveness of classroom management, but the factor of achievement motivation and self-concept in alleged investigators are factors that are closely related to the effectiveness of classroom management. Teacher who has high achievement motivation and high self-concept will try to succeed in carrying out the tasks. To be successful it is, among other things he should be able to demonstrate effective classroom management. Under these conditions, researchers interested in conducting research on the effectiveness of teachers in classroom management at state junior high school(MTsN) 2 Medan, Indonesia in conjunction with achievement motivation and self-concept.

\subsection{The Purpose of Study}

The purpose of this research is to study the relationships of achievement motivation and self-concept on the effectiveness of teacher's classroom management at State Junior High School (MTsN) 2 Medan in Indonesia

\section{Literature Reviews}

2.1 Effectiveness of classroom management

An activity is said to be effective when the activities that can be completed in a timely manner and achieve the desired goal (Warsita, 2008). The effectiveness as part of a success, both in terms of technical and non-technical skills to do the work (Duke, 1987). Robbins and Cenzo (1988) said that the effectiveness as a result of activities done something right in order to achieve a predetermined goal.

In the context of the process of learning, classroom management can be defined as the various types of activities undertaken by teachers to create and maintain an optimal learning conditions(Achsin, 1990).

According to Winataputra (2001), classroom management is basically the arrangement of people and goods that enable the creation and maintenance of optimal learning conditions. Therefore, teachers need to master the art of managing the class. According to Marland (1990), there are three signs of success teachers: (1) The attitude of caring and unyielding; (2) Explanation is easy to understand; and (3) good classroom management.

Wong and Wong (1998) said that classroom management has two objectives, namely to increase student engagement and to create a conducive learning environment. With respect to the objectives expected of classroom management can be implemented effectively. According Soemanto (1990) classroom management of teachers will be effective if there supporting factors that can create an atmosphere classroom conducive and can increase student engagement in the learning process. Teachers should be able to organize and manage the classroom in a way that creates an impression that reflects a beautiful garden, peaceful, safe, quiet, and fun for all students to engage in learning (Suprihatiningrum, 2016).

\subsection{Achievement Motivation}

Achievement motivation is the hope to get satisfaction in completing a task that is difficult and challenging or certain impulse to behave in completing the task with a standard of excellence that results can be evaluated (Bigge and Hunt, 1979). In the opinion of Steer and Porter (1985) that the characteristics of people who have high achievement motivation include: 1) tend to work a moderate; 2) require direct feedback about its work; 3) get the satisfaction of having completed the task and 4) determine the objectives of the activity prior to carrying out the action and work so successfully. The success of a person to achieve the best standards, principally related to hope for success and a tendency to avoid failure (Berg, 1990). Thus achievement motivation causes people not only want to outperform a standard of the best, but he also wants to be successful in other things, so that they are ambitious and competing for success.

\subsection{Self-Concept}

In general terms, self-concept is a combination of thoughts, feelings, and attitudes people against itself (Woolfolk, 1985). Attitudes about themselves affect behavior and provide insight into the perceptions of individuals, individual needs and goals of individuals (Burn, 1984). Kosslyn and Rosenberg (2001) said that self-concept refers to the beliefs, desires, values, and traits that defined a person against himself. Confidence in oneself, will determine the actions and views on the world and others (Clark, 1988). The self-concept consists of a general self-concept, self-concept of academic and nonacademic self-concept. The general self-concept is a combination of academic self-concept and non-academic self-concept. Academic self-concept is the concept of self is closely linked to learning in schools, such as learning, subjects, work habits, and relationships with teachers and academic achievement (Bloom, 1976). Based on the results, the study showed that academic achievement has a stronger relationship with academic self-concept of the non-academic self-concept (Marsh, 1992). However, academic achievement tends to be consistent with the assessment of the individual (Everret, 1972). This means that individuals who have high academic achievement tend to have a positive selfassessment. 
2.1 Research site and of participants

\section{METHOD}

The research was conducted at StateJunior High School(MTsN) 2 Medan, Indonesia. The method used in this research is survey method with correlation technique. The number of samples in this study was 36 teachers. The sampling technique used is a random sampling.

\subsection{Data collection and analysis}

Data for this study were collected through a survey questionnaire developed by the researchers to examine the relationship between achievement motivation and self-concept and effectiveness of teachers' classroom management. The analysis technique used to test the hypothesis in this study was the statistical technique of regression and correlation (simple and double).

\section{RESULTS ANDDISCUSSION}

3.1 Results

3.1.1 Data on Classroom Management Effectiveness (Y)

Based on data netted from a 40-point declaration, the distribution of scores emperor's statement this teacher's classroom management effectiveness spread between the lowest score 123 up to 184. The highest score calculation of the distribution of scores resulted in a mean 158, 66, median 161 and mode 161, 32. Based the score of the respondents tend to have a normal distribution because of the price of mean, median, and mode close to the average.

Table 1: Frequency Distribution of Classroom Management Effectiveness Value

\begin{tabular}{|l|l|l|l|}
\hline No. & Class Interval & $\begin{array}{l}\text { Absolute } \\
\text { Frequency }\end{array}$ & $\begin{array}{l}\text { Relative Frequency } \\
(\%)\end{array}$ \\
\hline 1 & $123-133$ & 3 & 8,33 \\
\hline 2 & $134-144$ & 3 & 8,33 \\
\hline 3 & $145-155$ & 8 & 22,22 \\
\hline 4 & $156-166$ & 8 & 22,22 \\
\hline 5 & $167-177$ & 9 & 25,00 \\
\hline 6 & $178-188$ & 5 & 13,89 \\
\hline \multicolumn{2}{|l|}{ Jumlah } & 36 & 100,00 \\
\hline
\end{tabular}

\subsubsection{Data on Achievement Motivation $\left(\mathrm{X}_{1}\right)$}

Based on data netted from a 40-point declaration, the distribution of scores emperor to the statement of achievement motivation is spread between the lowest score to highest score of 114 to 160 . The theoretical score is 40 and 200. The calculation of the distribution of scores resulted in a mean 136.55, median 138.78, and modes 134.94. Based on this, the respondents tend to be normally distributed scores. Because of the price of mean, median, and mode close to the average.

Table 2: Frequency Distribution Value Achievement Motivation

\begin{tabular}{|l|l|l|l|}
\hline No. & Class Interval & $\begin{array}{l}\text { Absolute } \\
\text { Frequency }\end{array}$ & $\begin{array}{l}\text { Relative } \\
\text { Frequency }(\%)\end{array}$ \\
\hline 1 & $114-121$ & 6 & 16,66 \\
\hline 2 & $138-144$ & 5 & 13,89 \\
\hline 3 & $145-151$ & 6 & 16,66 \\
\hline 4 & $152-158$ & 11 & 30,55 \\
\hline 5 & $159-165$ & 6 & 16,66 \\
\hline 6 & $166-172$ & 2 & 5,55 \\
\hline \multicolumn{2}{|l|}{ Amount } & 36 & 100,00 \\
\hline
\end{tabular}

\subsubsection{Data on Self-Concept $\left(\mathrm{X}_{2}\right)$}

Based on data netted from a 42-point declaration, the distribution of scores emperor for teacher selfconcept statement is spread between the lowest score of 124 to 199 . The highest score a theoretical score is 42 and 210. The calculation of the distribution of scores resulted in a mean 165.38, median 167.44 and modes 
170.04. Based on this, the respondents tend to be normally distributed scores. Because of the price of mean, median, and mode close to average.

Table 3: Frequency Distribution of Self-Concept Values

\begin{tabular}{|l|l|l|l|}
\hline No. & Class Interval & $\begin{array}{l}\text { Absolute } \\
\text { Frequency }\end{array}$ & $\begin{array}{l}\text { Relative } \\
\text { Frequency (\%) }\end{array}$ \\
\hline 1 & $124-136$ & 4 & 11,11 \\
\hline 2 & $137-149$ & 4 & 11,11 \\
\hline 3 & $150-162$ & 5 & 13,89 \\
\hline 4 & $163-175$ & 13 & 36,11 \\
\hline 5 & $176-188$ & 7 & 19,44 \\
\hline 6 & $189-201$ & 3 & 8,33 \\
\hline \multicolumn{2}{|l|}{ Jumlah } & 36 & 100,00 \\
\hline
\end{tabular}

3.1.4 Hypothesis Testing

3.1.4.1The relationship between achievement motivation $\left(\mathrm{X}_{1}\right)$ and effectiveness of teachers' classroom management (Y).

Simple correlation analysis between $\mathrm{X}_{1}$ with $\mathrm{Y}$ produces a correlation coefficient $(\mathrm{r})$ of 0.57 . Testing significance correlation using t-test produces $t_{\text {calculate }}=5.11$. From the distribution list for $\mathrm{df}=34(\mathrm{n}-2)$ and the significance level of 0.05 was obtained $t_{\text {table }}=2.44$. It appears that the value of $t$ obtained from the analysis $\left(\mathrm{t}_{\text {calculate }}\right)$ is greater than the value of $\mathrm{t}$ contained in the table $\left(\mathrm{t}_{\text {table }}\right)$. This shows that the correlation coefficient of 0.57 is significant. The coefficient of determination is the square of the correlation coefficient between $\mathrm{X}_{1}$ with $\mathrm{Y}$ is equal to $(0.57)^{2}=0.3249$. It showed that about $32.49 \%$ of the variation in the effectiveness of teachers' classroom management can be explained by variations in achievement motivation The calculation result shows $\mathrm{ry}_{2.1}$ partial correlation of 0.43 and $\mathrm{t}_{\text {calculate }}=3.05>\mathrm{t}_{\text {table }}=2.44$ at a significance level of 0.05 . Thus the null hypothesis is rejected and otherwise, the alternative hypothesis is accepted. The conclusion is that there is a positive relationship between achievement motivation and effectiveness of teachers' classroom management.

3.1.4.2 The relationship between self-concept $\left(\mathrm{X}_{2}\right)$ andeffectiveness of teachers' classroom management $(\mathrm{Y})$

Simple correlation analysis between $\mathrm{X}_{2}$ and $\mathrm{Y}$ produces a correlation coefficient ( $\mathrm{r}$ ) of 0.48 . Testing significance correlation using t-test produces $t_{\text {calculate }}=3.22$. From the distribution list for $\mathrm{df}=34(\mathrm{n}-2)$ and the significance level of 0.05 was obtained $t_{\text {table }}=2.44$. It appears that the value of $t$ obtained from the analysis $\left(t_{\text {calculate }}\right)$ is greater than the value of contained in the table $\left(t_{\text {table }}\right)$. This shows that the correlation coefficient of 0.48 is significant. The coefficient of determination is the square of a correlation coefficient between $\mathrm{X}_{2}$ with $\mathrm{Y}$ is equal to $(0.48)^{2}=0.23$. It shows that about $23 \%$ of the variation in the effectiveness of classroom management can be explained by variations in the self-concept of teachers. The calculation result shows ry ${ }_{1.2}$ partial correlation of 0.41 and $\mathrm{t}_{\text {calculate }}=2.90>\mathrm{t}$ table $=2.44$ at a significance level of 0.05 . Thus the null hypothesis is rejected and otherwise, the alternative hypothesis is accepted. The conclusion is that there is a positive relationship between self-concept and effectiveness of teachers' classroom management (Y).

3.1.4.3 Relations Achievement Motivation $\left(\mathrm{X}_{1}\right)$ and the concept of Self $\left(\mathrm{X}_{2}\right)$ together with

Teacher Classroom Management Effectiveness (Y)

Multiple correlation analysis between the $\mathrm{X}_{1}$ and $\mathrm{X}_{2}$ with $\mathrm{Y}$ produces a correlation coefficient ( $\rho \mathrm{y}_{\cdot 12}$ ) of 0.62. Testing significance correlation using F-test yield $F_{\text {calculate }}=19.5$. From the list of the F distribution with 2 df numerator and denominator df 33 at a significance level of 0.05 was obtained $F_{\text {table }}$ is 3.29 , it appears that the value of $F_{\text {calculate }}$ is greater than the value $F_{\text {table. }}$ It shows that a significant $F_{\text {calculate }}$ and also a significant correlation of 0.62 . The null hypothesis is rejected, and otherwise, the alternative hypothesis is accepted. The conclusion is a positive relationship between achievement motivation and self-concept of teachers together with the effectiveness of teachers' classroom management. The coefficient of determination obtained by $(0.62)^{2}=$ 0.3844 . This shows that $38.44 \%$ of the variation in the effectiveness of teachers' classroom management can be explained by variations in achievement motivation and self-concept of teachers together.

\subsection{Discussion}

The research focus is on the effectiveness of classroom management in conjunction with the motivation and self-concept. The results of this study are consistent with the view Arikunto (1990) that there are two factors that affect a person's performance, namely internal factors, and external factors. Internal factors consist of attitudes, interests, intelligence, motivation and personality, while external factors including facilities, infrastructure, incentives, or salary, work conditions and work environment. According to Arikunto,that 
achievement motivation and self-concept are important factors that can affect a person's performance, including the effectiveness of teachers' classroom management.

Some of the findings in this study indicate that the achievement motivation of teachers in state junior high school (MTsN) 2 Medan has a positive relationship with the effectiveness of the management class. This is in line with the opinion of Tafiardi (1996) that the achievement motivation sort of mental virus that if it occurs in a person, tends to cause people to act vigorously to achieve an outcome or achievements include work performance. In addition, this study showed that self-concept has a positive relationship with the teacher's classroom management effectiveness. These conditions are very conducive to be considered in improving the effectiveness of classroom management that ultimately led to the advancement state junior high school (MTsN) 2 Medan.

Achievement of the effectiveness of classroom management better still many obstacles. According to this study, dependence on the effectiveness of the teacher to the classroom management teacher achievement motivation and self-concept variables only amounted to $38.44 \%, 61.56 \%$ this means that there are other factors contribute to the effectiveness of teachers' classroom management that need attention. These factors include the interests, attitudes, intelligence, emotional intelligence, salaries or incentives, infrastructure, work environment, and leadership. However, it is also possible the effectiveness of teachers' classroom management would be better to increase both independent variables studied in this research.

Efforts to improve achievement motivation and self-concept of teachers, among others, may be made by the leaderstate junior high school(MTsN) 2 Medan, Indonesia and entities associated with conducting intensive training on improving achievement motivation and self-concept to teachers in public junior high school (MTsN) 2 Medan. In addition, efforts to increase achievement motivation and self-concept can also be done by growing self-love work, provide appropriate incentives for each job that has been done, build a good relationship between superiors and subordinates or with fellow colleagues, as well as to provide an assessment of performance periodically.

\section{CONCLUSSION}

Based on hypothesis testing that has been described above, it can be drawn some conclusions as follows: (1) there is a positive relationship between achievement motivation and the effectiveness of teacher's classroom management, meaning that the higher the achievement motivation higher the effectiveness of teacher's classroom management; (2) there is a positive relationship between self-concept and the effectiveness of teacher's classroom management, meaning that the higher the self-concept of teachers the higher the effectiveness of teacher's classroom management, and (3) there is a positive relationship between achievement motivation and self-concept of teachers together with the effectiveness of teachers'classroom management, meaning that the higher the achievement motivation and self-concept of teachers the higher the effectiveness of teachers' classroom management.

\section{REFERENCES}

[1] Achsin, Amir. 1990. Pengelolaankelasdaninteraksibelajar -Mengajar, Ujung Pandang: IKIP Ujung Pandang.

[2] Arikunto, Suharsimi. 1990. Manajemenpenelitian, Jakarta: Rinekacipta.

[3] Berg, R. C.1990. Motivation Theories And Principles, New Jersey: Prentice Hall Englewood Cliffs.

[4] Bloom, B. S. 1976. Human Characteristics And School Learning. New York: Mcgraw-Hill.

[5] Burns, R.B. 1984. The Self-Concept: Theory, Measurement, Development And

[6] Behaviour. London: Longman.

[7] Clark, Barbara. 1988. Growing Up Gifted, Columbus, Ohio: Merill Publishing Company.

[8] Duke, D. L. 1987. School Leadership And Instructional Improvement, New York: Random House.

[9] Everett, A.E. 1996. "The Self-Concept Of High, Medium, And Low Academic Achievers",

[10] Personality And Educational Achievement, Ed. F.D Naylor, Sydney: John Willey And Sons Australia Pty., Ltd.

[11] Indrafachrudi, Soekarto And Lamberi, Busro. Pengantarkepemimpinanpendidikan, Surabaya: Usaha Nasional, 1983.

[12] Marland, Michael. 1990. Senimengelolakelas, Translate Anonim, Semarang: DaharaPrize.

[13] Marsh, H. W. 1992. Content Specificity Of Relation Between Academic

[14] Achievement And Academic Self-Concept," Journal Of Educational Psychology Vol. 84.

[15] Robbins, S. P. And Cenzo,D. A. 1988. Fundamentals Of Management, New

[16] Jersey: Prentice Hall International, Inc., 1988.Soemanto, Wasty. 1990. Pengelolaankelas, Jakarta: Rinekacipta.

[17] Suprahatiningrum, Jamil. 2016. Strategipembelajaran: Teoridanaplikasi, Yogyakarta: Ar-Ruzz Media. 
[18] Steer, Richard And Poter, L.W. 1985. Motivation And Work Behaviour, New York: Mcgrawhill Book Company.

[19] Tafiardi. 1996. Membudayakanmotivasiberprestasi Di Lingkungankerja, Bulletin Ekonomi No. 6 Tahun XXI.

[20] Winataputra, U. S. 2001. Strategibelajarmengajar, Jakarta: Universitas Terbuka.

[21] Wong, Hary And Wong, Rosemary. 1998. Effective Classroom Management.(Http://Www.Learr C./Org/Newlnc/Carepa.)

[22] Woolfolk, A. E. 1985. Educational Psychology, Singapore: Mcgraw-Hill Book, Co. 